\title{
First Report of Mesocyclops parentium Holynska, 1997 (Copepoda : Cyclopidae) from Subterranean Water Source of Kerala, India and a Checklist of such Copepods
}

\author{
S. Resmi, K.V. Jayachandran* \\ Department of Fisheries Resource Management, \\ School of Fisheries Resource Management \& \\ Harvest Technology, Kerala University of Fisheries \\ and Ocean Studies, Kochi 682506, Kerala, India
}

Study Area: Perumbavoor \& Navaikulam of State Kerala, India Coordinates: $10^{\circ} 10^{\prime} 69^{\prime \prime} \mathrm{N}, 76^{\circ} 47^{\prime} 37^{\prime \prime} \mathrm{E} \& 8^{\circ} 77^{\prime} 36^{\prime \prime} \mathrm{N}, 76^{\circ} 78^{\prime} 89^{\prime \prime} \mathrm{E}$

Key words: Mesocyclops parentium, M. pehpeiensis, Copepods, Subterranean water. .

\section{Abstract}

Freshwater copepods belong to 3 families out of 112 families under three orders, namely, Calanoida, Cyclopoida and Harpacticoida. Reports on the copepod representatives in subterranean habitats are rare. During the present study, two species of the genus Mesocyclops Sars, 1914 , namely, M. parentium Holynska, 1997 and $M$. pehpeiensis $\mathrm{Hu}, 1943$ have been reported from well waters which do not have any contact with open water systems from Perumbavoor and Navaikulam. The present paper is the report of these species from subterranean sources of waters and a preliminary checklist of such other species. M. parentium Holynska, 1997 has been re-described also. The two species reported in the present paper show subterranean /groundwater/well water as well as in open water occurrences are biologically interesting.

\section{Introduction}

Biodiversity studies on freshwater copepods of India are still in its infancy stage. A few noteworthy studies on the group have been already carried out from different parts of India (Gurney, 1906; Sewell, 1919, 1924; Kiefer, 1932, 1939, 1981; Ranga Reddy, 1977; 1985; 2000; 2013, 2014; Karanovic \& Ranga Reddy, 2005; Mayan, 2006; Ranga Reddy \& Defaye, 2008; Ambedkar, 2012; Resmi, 2014; Jayachandran \& Resmi, 2014; Resmi \& Jayachandran, 2014). It has been reported that a few species of copepods do occur exclusively in subterranean water source or in caves (Ito, 1960; Pesce \& Maggi, 1981; Dumont \& Maas, 1985; Karanovic \& Ranga Reddy, 2005; Ranga Reddy \& Defaye, 2009). During the present study on the freshwater copepods of Kerala waters, interestingly a recently described species, Mesocyclops

*Corresponding Author: chandrankvj@gmail.com 
parentium Holynska, 1997 was found to occur in wells also and is not connected with open water systems. The present paper is a report of this interesting case, occupy both in open and subterranean waters and the species has been re-described also. Yet another species reported from deep well of Kerala waters in the present paper is M. pehpeiensis Hu, 1943. The paper also provides a checklist of freshwater subterranean copepod fauna as a fundamental data for further investigation.

\section{Materials and Methods:}

The species has been collected from a newly dug out well near Perumbavoor, Ernakulam District, Kerala State $\left(10^{\circ} 10^{\prime} 69^{\prime \prime} \mathrm{N}, 7^{\circ} 47^{\prime} 37^{\prime \prime} \mathrm{E}\right)$. The well is situated at an elevation of about 12 meters above MSL. This area has no connection with open river system. The well has been dug out in lateritic soil and has a depth of 12-15 feet. The source of water is ground water subterranean channels. Specimens were collected by pumping out water from well and it was filtered through a plankton net of mesh size $60 \mu \mathrm{m}$ on 25-09-2013. The species was identif ied with the help of literatures (Holynska, 1997; Ueda \& Reid, 2003). Permanent slides were prepared by using Bee's wax and it was sent to Prof. Maria Holynska, Museum and Institute of Zoology, Polish Academy of sciences, Wilcra, Poland the discoverer of the species for conf irmation. The body parts were drawn by using mirror type Camera Lucida attachment. The $M$. parentium is again described here in with view to help for further investigation. In the present study, M. pehpeiensis $\mathrm{Hu}, 1943$ is reported from a deep well (subterranean source about 70 feet depth) at Navaikulam, Thiruvanathapuram District, Kerala State $\left(8^{\circ} 77^{\prime} 36^{\prime \prime} \mathrm{N}, 76^{\circ} 78^{\prime} 89^{\prime \prime} \mathrm{E}\right)$. Specimens were collected by pumping out water from well and it was filtered through a plankton net of mesh size $60 \mu$ m on 11-05-2013. The present collection of the species has been compared for taxonomic identity by consulting Guo (2000). Diagnosis of M. pehpeiensis is also given in the text. The preliminary checklist was prepared by consulting literature (Ueda \& Reid, 2003; Ranga Reddy \& Defaye, 2008; Ranga Reddy, 2014).

\section{Results:}

The paper presents re-description of M. parentium, first report of M. pehpeiensis from subterranean source of Kerala waters and a preliminary checklist of species that occur in the different subterranean water sources.

\section{Re-description of Mesocyclops parentium Holynska, 1997}

Typelocality: Chalakkudy, Kerala

Adult female with body length excluding caudal setae is $1.0-1.2 \mathrm{~mm}$. Prosome: $1.5-2.2$ times as long as urosome (excluding caudal setae) and $1.2-1.35$ times as long as maximum width. Antennule 17-segmented and last two segments with finely serrate hyaline membrane. Hyaline membrane of last segment with a markedly large notch near the distal end; segments 1, 4-5, 7-13 adorned with spinules on ventral surface. Segments $1,4 \& 5$ with scattered shallow pits on posterior surface. The armature formula: $8 \mathrm{~s}, 4 \mathrm{~s}, 2 \mathrm{~s}, 6 \mathrm{~s}, 4 \mathrm{~s}$, ls+lsp, 2s, Is, Is, o, Is, ls+lae, o, Is, 2s, 3s, 7s+1ae (Figs. 2 - 4). Antenna consists of coxopodite, basipodite, and three-segmented endopod with $0,3,1,7,8$ setae respectively. Caudal spinule ornamentation on antennal basipodite: long spinules on lateral rim, near base; oblique row of spinules (10) next to spinules on lateral rim; very small spinules on medial rim; longitudinal row of long spinules (16) along lateral rim which are slightly increasing distally (distal spinules longer than proximal spinules); oblique row of fine spinules beginning at distal half of medial rim (as "leuckarti pattern"). In addition to these leuckarti pattern diffuse patch of spinules medially to oblique row of fine spinules beginning at distal half of medial rim; field of tiny spinules near implantation of medial setae and group of spinules near distal rim. Frontal spinule ornamentation on antennal basipodite: Longitudinal row of 25-32 spinules along lateral rim and a 
transverse row of spinules along proximal rim (Figs.- 5,6 ).

Labrum with toothed distal margin and long hairs present on the ventral and lateral surfaces (Fig. 7). In mandible, palp single segmented with two long and one short setae. Near the palp three groups of spinules on frontal surface. Spinules forming transverse row conspicuously larger than others (Fig. 8). In maxillula, precoxopodite arthrite with three claws distally, at their base one spiniform seta on ventral surface. Two medium-sized and three small spiniform setae on inner rim. A few setae present on the proximal part. Palp with one spine and two setae apically, one small external seta proximally, and three seta of almost equal size on external lobe. Spinules absent on palp (Figs. 9, 10). Maxilla consists of coxopodite, basipodite, and single segmented endopod. Precoxopodite bears one endite with two setae, coxopodite has one endite with one seta. Basipodite with two setae, the longer one inserted in front of the claw-like basal endite armed with strong teeth. Caudal surface of maxillary coxopodite with a group of fine spinules. One-segmented endopod with five setae apically (Fig. 11). Maxilliped with coxopodite, basipodite and two-segmented endopod. Coxopodite with three inner setae. Basipodite with two setae. Long spinules on inner margin and frontal surface below the insertion of basal setae. Two groups of spinules arranged caudally near lateral margin. Endopod l with one stout seta. Endopod 2 with three setae of increasing length from outermost to innermost (Fig. 12).

Medial expansion of basipodite of $\mathrm{P}_{1}-\mathrm{P}_{4}$ lacking a medial spine. Frontal surface of $\mathrm{P} 1$ basipodite with spinules arranged in semicircular arch. Lateral rim of leg 1-4 coxopodite with hairs. Intercoxal sclerite of leg 1-4 naked caudally and frontally. Two small acute outgrowths on intercoxal sclerite of $\mathrm{P}_{4}$ (Figs. 13-16). Caudal armature of $\mathrm{P}_{4}$ coxopodite with intermittent group of large spinules $(4+2+4)$ near distal rim ventrally; oblique row of long spinules in rows on lateral distal corner; long hairs next to and on lateral rim; rows of small spinules near proximal rim (Fig. 16). P4 endopod 3 with length/width $=$ 2.3-3.2; inner apical spine/outer apical spine $=1.4-1.55$; inner apical spine/endopod 3 length $=0.75^{-}$ o.83; both edges of inner and outer apical spine, except the proximal third, with teeth at full length. Apical seta of $\mathrm{P}_{5}$ 1.45-1.5 times and lateral seta 0.75-0.8 times as long as spiniform medial seta (Fig. 17). Long medial seta and two short spines of P6 about equal length (Fig. 17). Pediger 5 haired laterally and dorsally (Fig. 17). Genital double somite Length/Width 1.2-1.4 (Fig. 17). Lateral arms of seminal receptacle wide and short, weakly curved posteriorly; anterior margin of proximal part sinuate in the middle; horse shoe shaped copulatory pore. Transverse ducts form "V" fused near copulatory pore (Fig. 17).

Distal margin of anal segment with several well-developed spinules ventrally and dorsally, and only a few intermittent ones on lateral surface. The small spinules that form a semicircular oblique field (or row) are present on both side of the proctodaeum (dorsal surface of anal somite). Caudal ramus 2.5-3.2 times as long as wide and medial hairs absent. No spinules present at implantation of lateral seta, but present in the lateral most terminal setae. Spinules present on the ventral surface of caudal rami. Dorsal caudal seta o.8 - 1.o times as long as lateral most terminal caudal setae. Relative lengths of terminal caudal setae from medial most to lateral most:2.2-3.2, 5-6.7, 3.4-4.7, 1.o (Fig. 1).

Distribution: Chalakudy River, South India (Marsh) and Sri Lanka (Swamps) (Holynska, 1997; Ueda \& Reid, 2003).

Remarks: M. parentium is a rare species of copepod in Kerala waters. This species has been originally reported from River Chalakkudy and then from swamps of Sri Lanka. During the present study this species has been collected from an underground source of water and that too from a newly dug out well.

The specimens of the species agree fully with the characters given in the original description by 
Holynska (1997). However certain modifications have been met with are (based on Holynska, 1997; Ueda \& Reid, 2003): the endopod of antenna contains 8 setae instead of the 7 already reported. The pattern of spinule ornamentation of antennary basipodite in the present specimens differs from the original description. Diffuse patch medially to oblique row of fine spinules beginning at distal half of medial rim of caudal suface of antennary basipodite in the present specimens exhibits difference with the pattern as in original description. In the anal somite, presence of small spinules that form a semicircular oblique field (or row) on both side of the proctodaeum in the present specimens has not been recorded earlier. The differences noted are only intraspecif ic. The present report is an extension of distributional range and new habitat for the species.

\section{Diagonosis of Mesocyclops pehpeiensis Hu, 1943}

Synonyms:

Mesocyclops leuckarti pehpeiensis $\mathrm{Hu}, 1943$

Mesocyclops ruttneri Kiefer, 1981;

non Mesocyclops pehpeiensis: Lim and Fernando, 1985

Type locality: Pehpei, Sichuan, China

\section{Diagnosis:}

Copepod of the genus Mesocyclops having 17 segmented Antennule, last two segments with finely serrate hyaline membrane. Hyaline membrane of last segment extending behind implantation of medial seta of segment, with 1 large notch; ventral spinules present on segments 1, 4, 5, 7-13. Antenna with coxopodite, basipodite, and three-segmented endopod with o, 3, 1, 7, 8 setae respectively. Caudal spinule ornamentation on antennal basipodite: long spinules on lateral rim, near base; oblique row of spinules (7) next to spinules on lateral rim; longitudinal row of long spinules (915) along lateral rim; a row of spinules next to implantation of medial setae; oblique row of fine spinules beginning at distal half of medial rim and group of spinules near proximal rim. Frontal spinule ornamentation on antennal basipodite: longitudinal row of 17-22 spinules along lateral rim and transverse row distally to spinules along proximal rim.

Two large and acute outgrowths on intercoxal sclerite of $\mathrm{P}_{4}$, reaching about $1 / 3$ height of medial expansion of basipodite. Caudal armature of $\mathrm{P}_{4}$ coxopodite with continous or intermittent group of large spinules $(5+4)$ near distal rim ventrally; long spinules arranged in one row or group near to lateral margin; a few spinules in one row along proximal rim; long hairs on lateral rim. Apical seta of $\mathrm{P}_{5}$ with 1.1-1.4 times and lateral seta 0.5-1.3 times as long as spiniform medial seta. Pediger 5 without hair laterally and dorsally.

Seminal receptacle have wide and long lateral arms; anterior margin of proximal part sinuate in the middle; horse shoe shaped copulatory pore. Transverse ducts form "V" fused near copulatory pore; curvature of copulatory duct varying from straight to strongly curved. Distal margin of anal segment with continous row of well-developed spinules ventrally, dorsally and laterally. Spinules present at implantation of lateral seta and lateral most terminal setae.

Distribution: From central Asia (Uzbekistan, southern Kazakhstan) through India, Sri Lanka, IndoChina and China as far as Japan (Hokkaido) (Suarez-Morales et al., 2005). In the present study the species is reported from a deep well at Navaikkulam, Thiruvanathapuram District, Kerala State, India (subterranean sourceabout 70 feet depth).

Remarks: The size of this species seems to be variable according to different geographic areas. The Chinese populations of females, however, have a tendency to be larger (1.2-1.7 $\mathrm{mm}$ ) than the American 


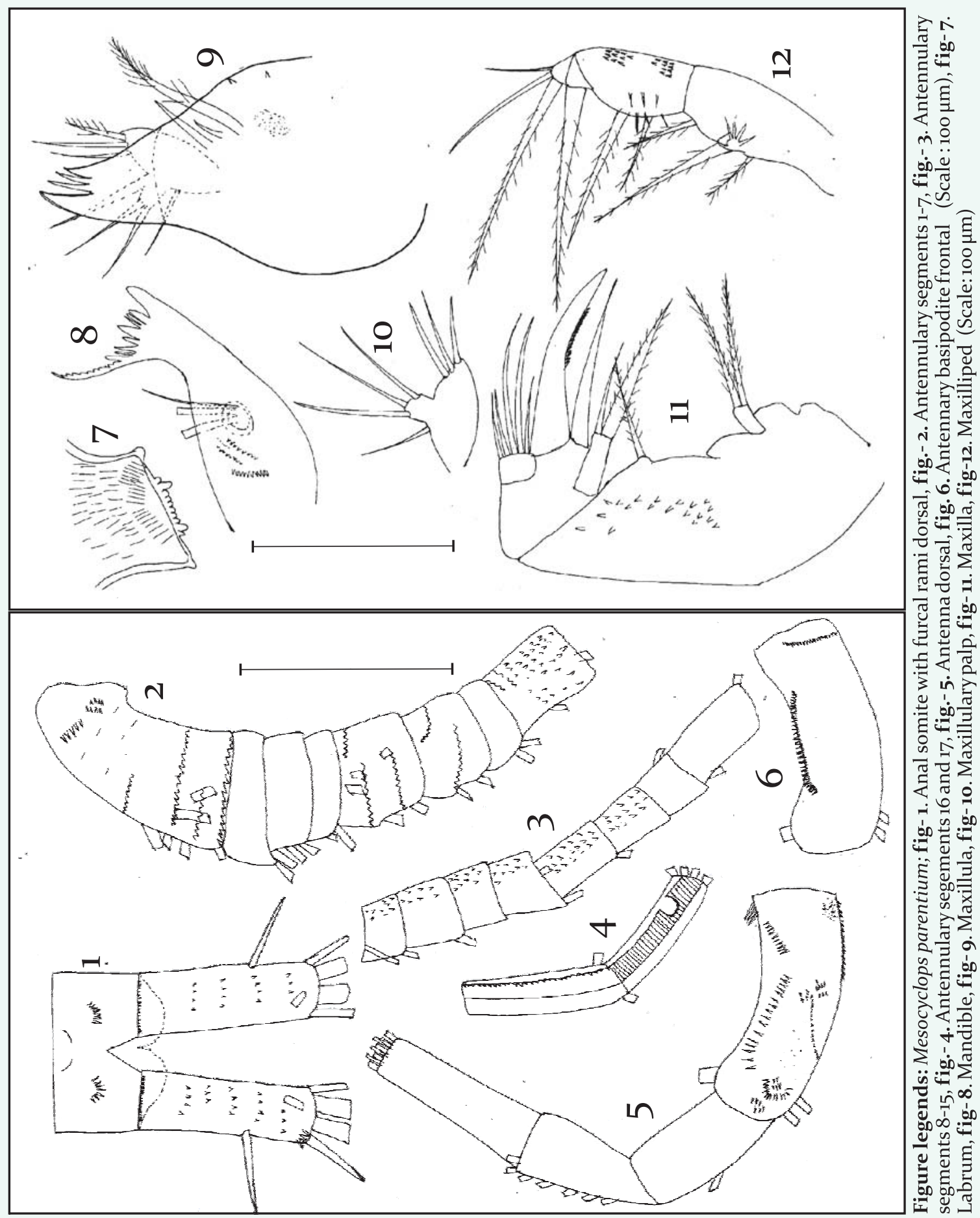

Ambient Science (2014)

http://www.caves.res.in/

Vol.-1(2): p 51 

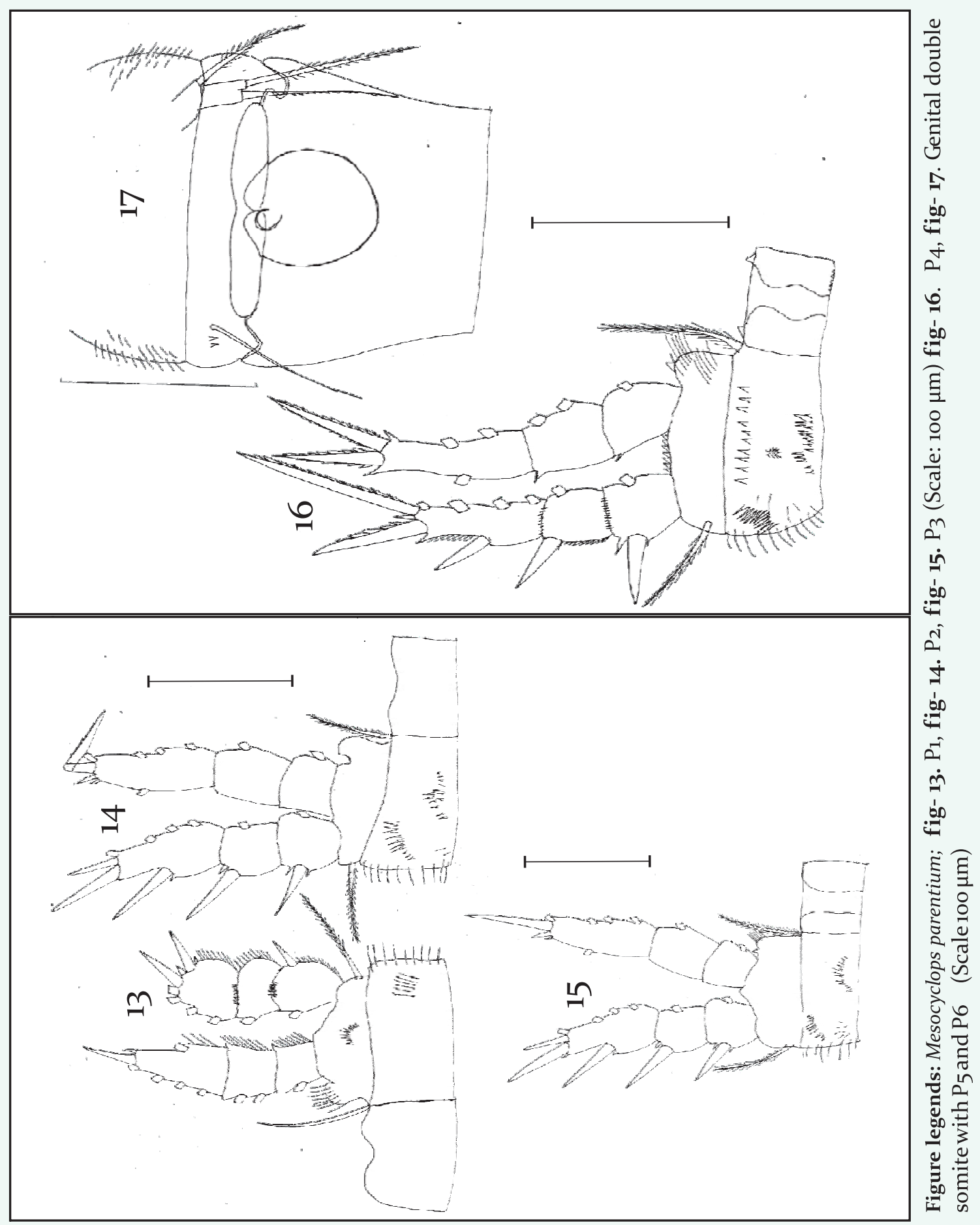

Ambient Science (2014) 
ones (1.1-1.2 mm) (Suárez-Morales et al., 2005). The present specimens of M. pehpeiensis are coming in the size range of American forms. The Mexican specimens have clusters of cuticular pores on the ventral surface of the genital somite, which is absent in the Kerala specimens and according to SuárezMorales et al. (2005) Asian specimens might lack the pores on the surface of the genital somite and it was absent in the present specimens. This species already had been reported from wells but from Indian waters it is a first report.

\section{Discussion:}

Among 43 families of Calanoida, family Diaptomidae; 15 families of Cyclopoida, family cyclopidae and 54 families of Harpacticoida, family Canthocamptidae have representatives in freshwaters. From the gathered reports it can be seen that nearly 15 species are conf ined to subterranean sources. In that, 11 and 4 subterranean species belong to Orders Cyclopoida and Harpacticoida respectively. The two species reported in the present paper show subterranean/ground water/ well water as well as in open water occurrences are biologically interesting.

\section{Preliminary checklist of subterranean species:}

A tentative list of species reported from caves, subterranean, well waters has been provided below. It requires further review.

\begin{tabular}{|c|c|c|c|}
\hline \multicolumn{2}{|c|}{ Sl.No. Species } & \multirow[t]{2}{*}{ Source } & \multirow[t]{2}{*}{ Remarks } \\
\hline & Order Cyclopoida & & \\
\hline 1. & Thermocyclops uenoi Ito, 1952 & Well water, Japan & $\begin{array}{l}\text { Reported only from a well in } \\
\text { Kumamoto, Japan }\end{array}$ \\
\hline 2. & T. oblongatus Sars, 1927 & $\begin{array}{l}\text { Well water, New Delhi, } \\
\text { India }\end{array}$ & $\begin{array}{l}\text { Reported from open water } \\
\text { system other than well water. }\end{array}$ \\
\hline 3. & $\begin{array}{l}\text { Rybocyclops dussarti } \\
\text { Ranga Reddy \& Defaye, } 2008\end{array}$ & $\begin{array}{l}\text { Borewell, Andhra Pradesh, } \\
\text { India }\end{array}$ & $\begin{array}{l}\text { Known only from riparian bore } \\
\text { wells }\end{array}$ \\
\hline 4. & $\begin{array}{l}\text { Tropocyclops prasinus } \\
\text { Fischer, } 1860\end{array}$ & $\begin{array}{l}\text { Well water, New Delhi, } \\
\text { India }\end{array}$ & $\begin{array}{l}\text { Reported from open water } \\
\text { system other than well water }\end{array}$ \\
\hline 5. & $\begin{array}{l}\text { Mesocyclops aspericornis } \\
\text { Daday, } 1906\end{array}$ & $\begin{array}{l}\text { Well water, New Delhi, } \\
\text { India }\end{array}$ & Reported from open water \\
\hline 6. & M. chaci Fiers, 1996 & $\begin{array}{l}\text { Well water, Yucatan, } \\
\text { Mexico }\end{array}$ & $\begin{array}{l}\text { Reported from wells, karstic } \\
\text { crevices and subterranean pools }\end{array}$ \\
\hline 7. & M. yutsil Reid, 1996 & Cave, Mexico & $\begin{array}{l}\text { Reported only from large } \\
\text { subterranean waterbodies of the } \\
\text { karstic Yucatan plain. }\end{array}$ \\
\hline 8. & $\begin{array}{l}\text { M. cuttacuttae } \\
\text { Dumont and Maas, } 1985\end{array}$ & $\begin{array}{l}\text { Cave, Katherine, Northern } \\
\text { Territory, Australia }\end{array}$ & $\begin{array}{l}\text { Reported from a shallow pool in } \\
\text { a limestone cave of constant high } \\
\text { temperature, Cutta Cutta cave. }\end{array}$ \\
\hline 9. & $\begin{array}{l}\text { M. parentium } \\
\text { Holynska, } 1997\end{array}$ & Well water, Kerala, India & $\begin{array}{l}\text { Known from River water other } \\
\text { than well water }\end{array}$ \\
\hline 10. & M. pehpeiensis Hu, 1943 & $\begin{array}{l}\text { Well water, India* } \\
\left({ }^{*} \text { Not known precisely }\right)\end{array}$ & $\begin{array}{l}\text { Known from other open water } \\
\text { system other* than well water }\end{array}$ \\
\hline 11. & $\begin{array}{l}\text { Haplocyclops (Kiefercyclops) } \\
\text { fiersi Karanovic \& Ranga Reddy, } 2005 .\end{array}$ & $\begin{array}{l}\text { Bore wells, Andhra Pradesh } \\
\text { India }\end{array}$ & Reported only from bore well \\
\hline
\end{tabular}


Order Harpacticoida

12. Parastenocaris kotumsarensis Ranga Reddy \& Defaye, 2009

13. P.tirupatiensis Ranga Reddy, 2011

14. Elaphoidella crassa Chappuis, 1954

15. Neophyllognathopus bassoti (Rouch, 1972)
Cave, Chhattisgarh, India

Reported only from a cave, Kotumsar

Bore well, Andhra Pradesh, Reported only from bore well. India

Cave, Cherrapunji, Megalaya Reported only from a cave near India

India first cavernicolous harpacticoid species from India

Well and Bore well
Reported only from wells of Philippines and bore wells of Andhra Pradesh, India

\section{Acknowledgements:}

We wish to extend our sincere thanks to the Kerala University of Fisheries and Ocean Studies for providing necessary facilities for carrying out the research and to Dr. Maria Holynska for her valuable suggestions and support. The authors are also thankful to Dr. V. Ambilikumar, Associate Professor and Head of Management Studies, and to Mr. Beneesh, Laboratory Assistant, KUFOS for their personal help in the collection of the species from the wells of their houses. One of the authors (R) is grateful to DST for the INSPIRE fellowship for doing the research work.

\section{References:}

Ambedkar D. (2012): Morpho-taxonomy and biogeography of diaptomid copepods of India, with description of four new species of the genus Tropodiaptomus Kiefer, 1932 (Crustacea: Calanoida). Ph. D. thesis, Acharya Nagarjuna University, Nagarjuna Nagar, Andhra Pradesh, 222p.

Dumont H.J. \& Maas S. (1985): Mesocyclops cuttacutaen sp. from a cave in northern Australia (Crustacea: Copepoda, Cyclopoida). The Beagle, Occasional Papers of The Northern Territory Museum of Arts and Sciences, 1:115-122.

Guo X M. (2000): Two new species of Mesocyclops from southern China and notes on the genus Mesocyclops in China. Hydrobiologia, The Hague, 429:115-131.

Gurney R. (1906): On some freshwater Entomostracans in the collection of the Indian Museum, Calcutta. I. Asiatic. Soc. Bengal. 2 (7):273-281.

Holynska M. (1997) Tracing the routes of speciation in Mesocyclops woutersi-superspecies (Copepoda: Cyclopoida). Annales Zoologici, Warsaw, 47(3/4):321-336.

Ito T. (1960): Ground water copepods from the western part of Japan. Jap. J. Limnol., 21:131-140.

Jayachandran K.V. \& Resmi S. (2014): Manual on copepods. KUFOS: Instruction book II, 69 + I viii prelims.

Karanovic T. \& Ranga Reddy Y. (2005): First Halicyclops kiefer (Crustacea, Copepoda) from Indian sub-terranean waters: the most reduced free living cyclopoid. Ann. Limol. Int. J. Lim. 41 (2), 83-92.

Kiefer F. (1932): Versuch eines Systems der Diaptomiden (Copepoda, Calanoida). Zool.Jahrb. (Syst.), 63:451-520.

Kiefer F. (1939): Freilebende Ruderfusskrebse (Crustacea Copepoda) aus Nordwest und Sudindien (Pandschab, Kashmir, Ladak, Nilgirigebirge). Mem. Ind. Museum., 13: 83-202.

Kiefer F.(1981): Beitrag zur Kenntnis von morphologie. Taxonomie und geographischer Verbreitung von Mesocyclops leuckarti auctorum. Arch. Hydrobiologia. Suppl., 62(1):148-190.

Mayan A. (2006): Systematics and ecology of freshwater copepods. Ph.D. thesis, Calicut University, Kerala, 257p.

Pesce G.L. \& Maggi D. (1981): Cyclopoides et Calanoides des eaux phreatiques de la Grece meridionale et insulaire (Crustacea:Copepoda). Ecol. Mediterranea., 7:163-182.

Ranga Reddy Y. (1977): Studies on systematics and ecology of free-living freshwater copepods of Guntur and its 
environs (Andhra Pradesh, India). Ph.D. Thesis: Nagarjuna University: $462 \mathrm{pp}$.

Ranga Reddy Y. (1985): A taxonomic reappraisal of Spicodiaptomus chelospinus Rajendran (Copepoda, Calanoida). Crustaceana., 48:294-306.

Ranga Reddy Y. (2000): Neodiaptomus meggiti Kiefer, 1932: A rare South-East Asian species from Andaman Islands, India (Copepoda: Calanoida, Diaptomidae). Crustaceana, 73 (3):257-272.

Ranga Reddy Y. (2013): Neodiaptomus prateek n. sp., a new freshwater copepod from Assam, India, with critical review of generic assignment of Neodiaptomus spp. and a note on diaptomid species richness (Calanoida: Diaptomidae).J. Crustacean. Biol., 33:849-865.

Ranga Reddy Y. \& Defaye D. (2008): Discovery of the genus Rybocyclops Dussart, 1982 (Crustacea, Copepoda, Cyclopoida) in subterranean ground waters of southeastern India, with the description of a new species and its biogeographic significance. Zootaxa, 1810:40-50

Ranga Reddy Y. \& Defaye, D. (2009): Two new Parastenocarididae (Copepoda, Harpacticoida) from India: Parastenocaris muvattupuzha $\mathrm{n}$. sp. from a river and $P$. kotumsarensis $\mathrm{n}$. sp. from a cave. Zootaxa, 2077:31-55.

Ranga Reddy Y. (2014): On the little-known hyporheic biodiversity of India, with annotated checklist of copepods and bathynellaceans (Crustacea) and a note on the disastrous implications of indiscriminate sand mining. Lournal of Threatened Taxa, 6(1):5315-5326.

Resmi S. (2014): Copepod resources in the selected inland water bodies of Kerala and culture of a species as live feed. Ph. D. thesis, Kerala University of Fisheries and Ocean Studies, 271p (unpublished).

Resmi S. \& Jayachandran K.V. (2014): New records of Mesocyclops granulatus Dussart \& Fernando, 1988 and Thermocyclops maheensis Lindberg, 1941 (copepoda: cyclopoida) from freshwater ponds of Kerala, India. Lournal of Indian Fisheries Association. (in press).

Sewell R.B.S. (1919): A preliminary note on some new species of Copepoda. Rec. Indian Mus., 16:118.

Sewell R.B. S. (1924): Fauna of Chilka Lake. Crustacea, Copepoda. Mem. Indian Mus., .5: 771-851.

Suárez-Morales E., Gutiérrez-Aguirre M.A., Torres J.L. \& Hernández F. (2005): The Asian Mesocyclops pehpeiensis $\mathrm{Hu}, 1943$ (Crustacea, Copepoda, Cyclopidae) in Southeast Mexico with comments on the distribution of the species. Zoosystema, 27(2):245-256.

Ueda H. \& Reid J.W. (ed.) (2003): Guide to the Identification of the Microinvertebrates of the Continental Waters of the World, 2o. Copepoda: Cyclopoida. Genera Mesocyclops and Thermocyclops. Backhuys Publishers, Leiden, Netherlands, ISBN 90-5782-126-5, 318 pp. 